
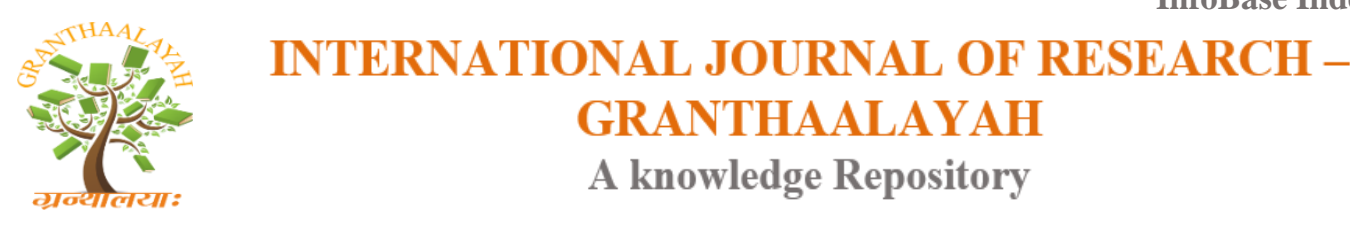

\title{
Social
}

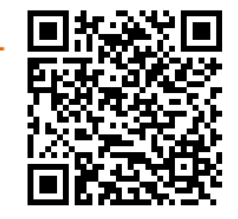

\section{KNOWLEDGE AND ATTITUDE OF M.Ed. TRAINEES TOWARDS ENVIRONMENTAL SUSTAINABILITY}

\author{
Deb Kumar Bhakta ${ }^{* 1}$, Abhijit Guha ${ }^{2}$ \\ ${ }^{* 1}$ Assistant Professor, Seacom B.Ed. College, Sankrail, Howrah, W.B., India \\ ${ }^{2}$ Associate Professor, Ramakrishna Mission Sikshanamandira, Belur Math, Howrah W.B., India
}

DOI: https://doi.org/10.29121/granthaalayah.v5.i6.2017.2003

\begin{abstract}
Environmental sustainability is a global concept today. It is an approach to deal with man' $\mathrm{s}$ relationship with resources, pollution, conservation, technology and urban and rural planning to the bio-sphere. Today, our environment is polluted due to various anthropogenetic factors. Educators, scientists, environment specialists and policy makers are rapidly pointing towards the human activities responsible for the destruction of the environment. To get rid of this problem, firstly we have to make the citizens aware. It can be done possible by the teaching-society. Therefore, the investigators made an attempt to find out the knowledge and attitude of M.Ed. trainees towards environmental sustainability. The investigators developed two tools- KEST and SMATES which had reliability co-efficient by Cronbach s alpha 0.749 and 0.656 respectively and were administered on 112 M.Ed. trainees randomly selected from 4 selected teachers' training colleges measuring their knowledge and attitude towards environmental sustainability. Collected data was analysed by various statistical techniques like mean, standard deviation, $t$ test and Pearson's correlation coefficient etc. through SPSS 20.0. The study revealed that educational stream had no significant impact on the difference of mean scores of knowledge and attitude of trainees towards environmental sustainability. On the other hand it was found that though gender had no significant impact on difference of mean scores of knowledge of trainees but it had significant impact on difference of mean scores of attitude of trainees towards environmental sustainability. Moreover, it was seen that knowledge and attitude towards environmental sustainability had significant moderate positive correlation $(r=0.445)$.
\end{abstract}

Keywords: Knowledge; Attitude; Environmental Sustainability; M.Ed. Trainee.

Cite This Article: Deb Kumar Bhakta, and Abhijit Guha. (2017). "KNOWLEDGE AND ATTITUDE OF M.Ed. TRAINEES TOWARDS ENVIRONMENTAL SUSTAINABILITY." International Journal of Research - Granthaalayah, 5(6), 102-110. https://doi.org/10.29121/granthaalayah.v5.i6.2017.2003. 


\section{Introduction}

The world faces today myriad problems related to the environment of global and local dimensions-depletion of resources, global warming, air, soil and water degradation, creation of waste, loss of forests, concretization of land and many others. Conferences organised by different National and International NGO Forums show that environment is the main agenda. The word Sustainable development" was first used by "World Commission on Environment and Development (Brundtland Commission) in 1987 in their publication ' Our Common Future. According to this commission, sustainable development is the ability of humanity to ensure that it meets the needs of present without compromising the ability of future generations to meet their own needs. Sustainable development has three major aspects which are called sustainable triangles viz. environmental sustainability, economic sustainability and social sustainability. United Nations 2005 World Summit Outcome Document refers that those three aspects of sustainable development are mutually interdependent. Ensuring environmental sustainability therefore has become one of the eight Millennium Development Goals established by the UN at the Millennium Summit, where all the member states agreed to achieve these goals by the year 2015. In order to protect and conserve the environment and enabling people to lead quality life, emphasis has been given to environmental education in both formal and non-formal system of education (Sundaravalli, 2012). In formal system of education, teachers play a very dynamic role in transmitting knowledge, attitude and concern to revert or at least control the damage that has been caused to the environment. A precondition to it remains, that teachers must possess skills to educate, train and sensitize students about the environmental issues. The inclusion of sustainable development' in B.Ed. syllabus of teacher training programme is very much relevant. The National Policy on Education-1986 (India) and NCFSE-2005 highlight the need for including Environmental concerns at all the levels of schoolings. The Honorable Supreme Court of India has endorsed a model syllabus (2004) prepared by the NCERT for introducing environmental studies as a compulsory school subject. With all effort from agencies responsible for determining quality education, school teachers have the major duty to install values and attitude among students through the subjects they are teaching in school so that students could behave sensibly towards the environment and contribute towards sustainable development. For this noble task, it is necessary that teacher training programme should be designed to equip trainee teachers for inculcating attitude through different subjects and this requires that pupil teachers should have positive attitude towards environment to manifest responsible environmental behavior (Lahiri, 2011). That' s why, Dubey and Dubey (2003) and Bhattacharya (2003) said that, Environmental Education should have an important issue in pre-service teacher education curriculum. Due to those reasons the researchers is trying to find out the attitude of teacher-trainees towards environmental sustainability. Hence, the present study may open an avenue for research in curriculum reform for teacher training programme encouraging innovative pedagogical approach to be practiced in school.

\section{Review of Related Literature}

Dixit and Aggarwal (2009) found that environmental awareness of prospective elementary teachers was in a positive direction. Ekambaram and Nagaraja (2010) found that B.Ed. students of science stream had higher level of environmental awareness than B.Ed. students of non-science stream. Arunkumar (2012) made a study to assess the environmental awareness of 
300 teacher-trainees. The study revealed that there was no significant difference between male and female teacher-trainees in environmental awareness. In the study of Kaur (2012), it was found that B.Ed. students had fairly good level of environmental awareness and gender had no impact on environmental awareness of B.Ed. students. Sahay and Singh (2013) found that male and female B.Ed. students of Patna Regional Centre of IGNOU had almost same knowledge of environmental issue. Remarkable high level of environmental awareness of B.Ed. students was found by Asthana and Divedi (2015).

\section{Objectives}

The following are the objectives of the present study-

1) To know the level of knowledge and nature of attitude of M.Ed. trainees towards environmental sustainability.

2) To find out whether gender has any impact on significant differentiation of knowledge and attitude of M.Ed. trainees towards environmental sustainability.

3) To find out whether educational stream has any impact on significant differentiation of knowledge and attitude of M.Ed. trainees towards environmental sustainability.

4) To study the nature of relationship existing between knowledge and attitude of M.Ed. trainees towards environmental sustainability.

\section{Hypotheses}

On the basis of above objectives the researcher formulated following hypotheses-

$\mathbf{H}_{\mathbf{0}}$ 1: There is no significant difference between male and female in their knowledge of environmental sustainability.

$\mathbf{H}_{\mathbf{0}}$ 2: There is no significant difference among trainees belonging to different educational streams in their knowledge of environmental sustainability.

$\mathbf{H}_{\mathbf{0}}$ 3: There is no significant difference between male and female in their attitude towards environmental sustainability.

$\mathbf{H}_{\mathbf{0}}$ 4: There is no significant difference among trainees belonging to different educational streams in their attitude towards environmental sustainability.

$\mathbf{H}_{0}$ 5: There is no significant relation between knowledge and attitude towards environmental sustainability of M.Ed. trainees.

\section{Methodology of the Study}

\section{Sample}

Simple random sampling technique had been used for selection of training college as well as sample. 112 M.Ed. trainees were selected from four teachers-training colleges of two districts of South Bengal (Howrah and Kolkata). 


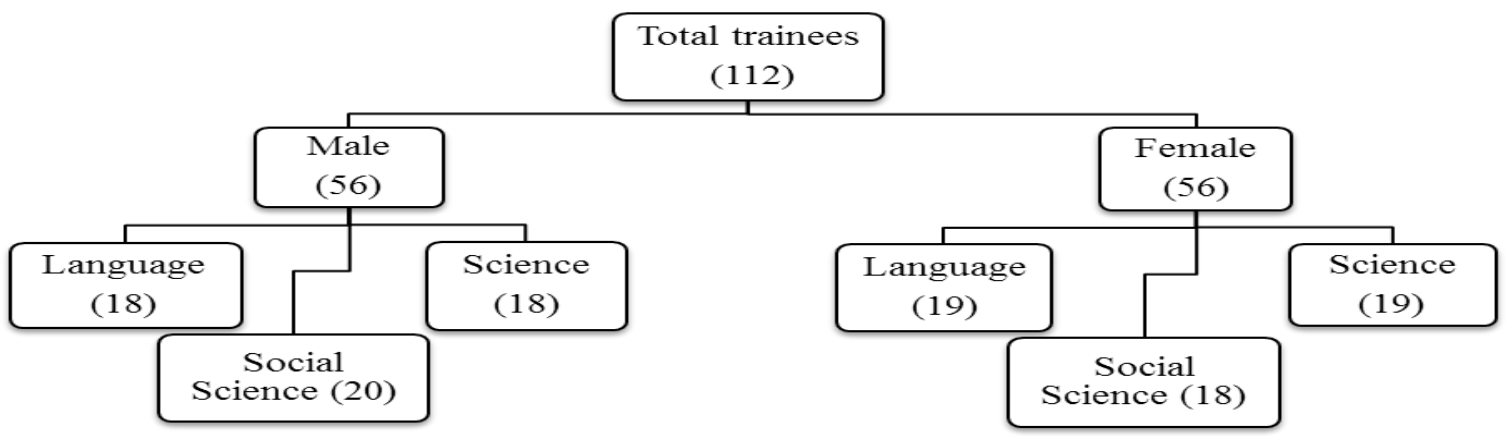

Figure 1: Detailed break-up of sample

\section{Variables}

In the present study, the researcher was considered two types of variables. These are given below-

1) Major Variables

i. Knowledge of Environmental Sustainability

ii. Attitude towards Environmental Sustainability

2) Categorical Variables

i. Gender (Male, Female)

ii. Educational stream (Language, Social-Science and Science)

\section{Tools Used}

Two researcher made tools had been used in the present study-

\section{i. Knowledge of Environmental Sustainability Test (KEST)}

It had 20 statements which were covering different dimensions of present environmental issues 1' mark is credited for each right answer and ' 0 ' for wrong answer. The reliability of this scale has been tested by Cronbach' $\mathrm{s}$ alpha and was found to be 0.749 .

ii. Scale for Measuring Attitude towards Environmental Sustainability (SMATES)

The scale had 25 statements which were covering different aspects of present environmental issues. This scale was a five- point Likert type scale containing strongly agree to strongly disagree. The reliability of this scale has been tested by Cronbach's alpha and was found to be 0.656 .

\section{Data Analysis and Interpretation}

The test of normality of data is very much essential for any quantitative research. If sample size is more than 3 but less than 2000 then normality of data is tested by Shapiro-Wilk test. If the significant value is more than $0.05(\mathrm{P}>0.05)$, then it can be said that data are normally distributed.

\begin{tabular}{|l|l|l|l|}
\hline \multicolumn{4}{|c|}{ Table 1: Test of Normality } \\
\hline Shapiro-Wilk \\
\hline Scale & Statistic & df & Sig. (P value) \\
\hline KEST & .872 & 112 & 0.062 \\
\hline SMATES & .889 & 112 & 0.075 \\
\hline
\end{tabular}


KEST $=$ Knowledge of Environmental Sustainability Test, SMATES $=$ Scale for Measuring Attitude towards Environmental Sustainability.

From table 1, it can see that the $\mathrm{P}$ values of Shapiro-Wilk test in case of Knowledge and Attitude towards Environmental Sustainability are 0.062 and 0.075 respectively. In both scale, $\mathrm{P}$ value is greater than 0.05 . So, it can be said that data of both scales are normally distributed. For these reasons the researcher has gone through parametric test for further analysis.

\section{Testing of Null Hypotheses}

\section{Testing of $\mathrm{H}_{0} \mathrm{I}$}

\begin{tabular}{|l|l|l|l|l|}
\hline \multicolumn{6}{|c|}{ Table 2: Group Statistics of KEST_Gender } \\
\hline \multirow{2}{*}{ KEST } & Gender & N & Mean & $\begin{array}{l}\text { Std. } \\
\text { Deviation }\end{array}$ \\
\cline { 2 - 5 } & Male & 56 & 15.50 & 2.815 \\
\hline
\end{tabular}

\begin{tabular}{|l|l|l|l|}
\hline \multicolumn{3}{|c|}{ Table 3: Independent Sample Test of KEST_Gender } \\
\hline \multirow{3}{*}{ KEST } & t-test for Equality of Means \\
\cline { 2 - 4 } & t value & df & $\begin{array}{l}\text { P value } \\
(2 \text { tailed })\end{array}$ \\
\cline { 2 - 4 } & -1.863 & 110 & 0.065 \\
\hline
\end{tabular}

\section{Interpretation}

From table 2, it is seen that mean score of female (16.39) in knowledge of environmental sustainability is higher than that of male (15.50) but difference is not significant because $\mathrm{P}$ value is $0.065(\mathrm{P}>0.05)$. So, $\mathrm{H}_{0} 1$ is retained. Therefore, it may be concluded that there is no significant mean difference between male and female trainees in their knowledge of environmental sustainability.

\section{Testing of $\mathrm{H}_{0} 2$}

\begin{tabular}{|c|c|c|c|c|}
\hline \multicolumn{5}{|c|}{ Table 4: Group Statistics of KEST_Educational stream } \\
\hline & Group & $\mathrm{N}$ & Mean & Std. Deviation \\
\hline \multirow[t]{3}{*}{ KEST } & Language & 37 & 15.59 & 2.783 \\
\hline & Social Science & 38 & 15.81 & 2.649 \\
\hline & Science & 37 & 16.43 & 2.217 \\
\hline
\end{tabular}

\begin{tabular}{|l|l|l|l|l|l|l|}
\hline \multicolumn{7}{|c|}{ Table 5: Result of One-way ANOVA of KEST_Educational stream } \\
\hline \multirow{3}{*}{ KEST } & Source of Variation & Sum of Squares & df & Mean Square & F & P value \\
\cline { 2 - 6 } & Between Groups & 13.968 & 2 & 6.984023 & & \\
& Within Groups & 715.710 & 109 & 6.566152 & & \\
\cline { 2 - 5 } & Total & 729.678 & 111 & & 1.063 & 0.348 \\
\hline
\end{tabular}

\section{Interpretation}

Table 4 depicts that mean score of knowledge of environmental sustainability of science group trainees is slightly higher than that of the rest two streams (Science > Social Science $>$ Language). But from table 6, it can be seen that obtained F (2/206) value is 1.063 which is not 
significant at 0.05 level of significance because $\mathrm{P}$ value is $0.348(\mathrm{P}>0.05)$. Hence, null hypothesis $\mathrm{H}_{0} 2$ is retained. It means that there exists no significant mean difference among the trainees belonging to three different educational streams (Language, Social-Science \& Science) in their knowledge of environmental sustainability of So, it can be concluded that knowledge of environmental sustainability of trainees belonging to different educational streams is uniformly same.

\begin{tabular}{|l|l|l|l|l|}
\hline \multicolumn{6}{|c|}{ Table 6: Group Statistics of SMATES_Gender } \\
\hline \multirow{2}{*}{ SMATES } & Gender & N & Mean & $\begin{array}{l}\text { Std. } \\
\text { Deviation }\end{array}$ \\
\cline { 2 - 5 } & Male & 56 & 95.46 & 9.604 \\
\cline { 2 - 5 } & Female & 56 & 100.35 & 7.176 \\
\hline
\end{tabular}

Testing of $\mathrm{H}_{0} 3$

\begin{tabular}{|l|l|l|l|}
\hline \multicolumn{4}{|c|}{ Table 7: Independent Sample Test of SMATES_Gender } \\
\hline \multicolumn{4}{|c|}{ t-test for Equality of Means } \\
\hline SMATES & t value & df & $\begin{array}{l}\text { P value } \\
\text { (2 tailed })\end{array}$ \\
\cline { 2 - 4 } & -3.053 & 110 & 0.002 \\
\hline
\end{tabular}

\section{Interpretation}

From table 6, it is seen that mean score of female (100.35) in attitude towards environmental sustainability is higher than male (95.46) and the difference is significant because $\mathrm{P}$ value is $0.002(\mathrm{P}<0.05)$. So, $\mathrm{H}_{0} 3$ is rejected. Therefore, it may be concluded that there is significant mean difference between male and female trainees in their attitude towards environmental sustainability.

\section{Testing of $\mathrm{H}_{0} 4$}

\begin{tabular}{|l|l|l|l|l|}
\hline \multicolumn{5}{|c|}{ Table 8: Group Statistics of SMATES_Educational stream } \\
\hline & Group & N & Mean & Std. Deviation \\
\hline SMATES & Language & 37 & 96.62 & 7.617 \\
\cline { 2 - 5 } & Social Science & 38 & 97.73 & 8.800 \\
\cline { 2 - 5 } & Science & 37 & 99.37 & 9.832 \\
\hline
\end{tabular}

\begin{tabular}{|l|l|l|l|l|l|l|}
\hline \multicolumn{6}{|c|}{ Table 9: Results of One-way ANOVA of SMATES_Educational stream } \\
\hline \multirow{3}{*}{ SMATES } & Source of Variation & Sum of Squares & df & Mean Square & F & P value \\
\cline { 2 - 7 } & Between Groups & 142.333 & 2 & 71.166 & & \\
& Within Groups & 8434.774 & 109 & 77.383 & & \\
\cline { 2 - 8 } & Total & 8577.107 & 111 & & 0.919 & 0.401 \\
\hline
\end{tabular}

\section{Interpretation}

Table 8 depicts that mean score of attitude towards environmental sustainability of science group trainees is slightly higher than that of the rest two streams (Science > Social Science $>$ Language). But from table 10, it can see that obtained F (2/206) value is 0.919 which is not significant at 0.05 level of significance because $\mathrm{P}$ value is $0.401(\mathrm{P}>0.05)$. Hence, $\mathrm{H}_{0} 4$ is retained. It means that there exists no significant mean difference of attitude of trainees belonging to three different educational streams (Language, Social-Science \& Science) towards 
environmental sustainability. So, it can be concluded that attitude of environmental sustainability of trainees belonging different educational stream is uniformly same.

\section{Testing of $\mathrm{H}_{0} 5$}

\begin{tabular}{|l|l|l|l|}
\hline \multicolumn{4}{|c|}{ Table 10: Result of Correlation between two variables } \\
\hline & & KEST & SMATES \\
\hline \multirow{3}{*}{ KEST } & Pearson Correlation & 1 & $0.445^{* *}$ \\
\cline { 2 - 4 } & Sign. (2 tailed) & & 0.000 \\
\cline { 2 - 4 } & $\mathrm{N}$ & 112 & 112 \\
\hline \multirow{3}{*}{ SMATES } & Pearson Correlation & $0.445^{* *}$ & 1 \\
\cline { 2 - 4 } & Sign. (2 tailed) & 0.000 & \\
\cline { 2 - 4 } & $\mathrm{N}$ & 112 & 112 \\
\hline
\end{tabular}

** Correlation is significant at the 0.01 level (2-tailed)

\section{Interpretation}

From the table 10, it can be seen that value of ' $\mathrm{r}$ ' is 0.445 for $\mathrm{df} 110$ is greater than critical value of ' $\mathrm{r}$ at 0.01 level of significance. So, $\mathrm{H}_{0} 5$ is rejected. It can be said that two variables have significant positive correlation. Moreover, the value of ' $r$ ' indicates that the strength of the relationship between two variables is moderate.

\section{Discussion and Conclusion}

From the present investigation, it was found that male and female trainees had insignificant difference in their knowledge of environmental sustainability. Similarly Sahay \& Singh (2012) and Asthana \& Divedi (2015) found that male and female trainees had no significant difference in their knowledge of environmental issues. But it was contradicted with the findings of Arunkumar (2012). The investigators found that science trainees had more knowledge than the trainees of other educational streams. This finding was corresponding with the result reached by Sundaravalli (2012). The study also revealed that male and female trainees had significant mean difference in their attitude towards environmental sustainability. This was contradicted with earlier findings of many researchers like Frrokhian (2012). The researchers also found that trainees belonging to different educational streams expressed similar pattern of attitude towards environmental sustainability. It was inconsistent with the result of a study conducted by Lahiri (2013). Moreover, the investigators found a significant and moderately positive correlation between knowledge and attitude of trainees towards environmental sustainability. It was consistent with the findings of many earlier researchers like Aminrad et el. (2012) and Lahiri (2013).

The present study revealed that gender had no significant impact on creating a difference of knowledge of trainees towards environmental sustainability. Moreover, it was found that educational stream had no such influence on the trainees in creating significantly different knowledge and attitude towards environmental sustainability. It can be concluded that knowledge of science may not play a crucial role in this regards. The study also revealed that knowledge of environmental sustainability and attitude towards environmental sustainability had a significant positive correlation. Generally our theoretical concept is that knowledge has an important role in building attitude. The researchers findings support this theoretical concept. So, 
the trainees' knowledge of environmental sustainability is very much necessary for building an attitude towards environmental sustainability.

In future trainees will be teacher-educators and by them directly or indirectly our future generation will be aware of environmental sustainability. Their knowledge and attitude towards environmental sustainability deeply influence their students and make them conscious about environmental awareness, pollution and degradation etc. This study will help the curriculum maker to include the principles of environmental awareness, protection of environment into present teacher-training curriculum because knowledge of environmental sustainability is helpful for building better attitude towards environmental sustainability. Moreover, educational stakeholders should conduct regular seminar, project and training for trainees for developing their knowledge and attitude towards environmental sustainability.

\section{References}

[1] Arunkumar, J. (2012). “ A Study on Assessment of Environmental Awareness among Teacher Trainees in Teacher Training Institutes." International Journal of Research in Social Sciences. 2(3), 312-321.

[2] Astalin, P.K. (2011). "A Study of Environmental Awareness among Higher Secondaery Students and Some Educational Factors Affecting It." International Journal of Multidisciplinary Research. 7(1), 90-101.

[3] Best, J.W. \& Kahn, J.V. (2008). "Research in Education (10th ed.)" . New Delhi, PHI Pvt. Ltd.

[4] Bhattacharya, S. (2003). "A Critical Analysis of Environmental Education Curriculum for Prospective Teachers", Paper presented in the National seminar on 36th Annual Conference on Environmental Education:-Perspective and Prospect organized by IATE and Department of Education Uttanchal, 13-15 March.

[5] Dubey and Dubey (2003). "Teacher Educator and Preparation of Teacher for Environmental Education" Paper presented in the National seminar on 36th Annual Conference on Environmental Education:-Perspective and Prospect organized by IATE and Department of Education, Uttanchal, 13-15 March.

[6] Farrokhian, F., Hosseinpur, M. and Soleimani, (2012). “ An Assessment of Elementary School Teachers Attitude towards Major Factors of Environmental Education in Countries: Case study in Iran.” Journal of Applied Environmental and Biological Sciences. 2(11), 12-19.

[7] Kant, S. and Sharma, Y. (2013). "The Environmental Awareness of Secondary School Students With Reference To Their Intelligence.” A Journal of Science, Technology and Management. 2(1), 33-39.

[8] Kaur, M. (2012). “ A Study of Environmental Awareness among B.Ed. Students”, International Indexed \& Referred Research Journal, I (01), 9-10.

[9] Koul, L. (2013). “ Methodology of Educational Research (4th ed.).” Noida, Vikas Publishing House Pvt. Ltd.

[10] Lahiri. S. (2011). “Assessing the Environmental Attitude among Pupil Teachers in Relation To Responsible Environmental Behavior: A Leap towards Sustainable Development." Journal of Social Sciences. 7 (1), 33-41.

[11] Mangal, S.K. (2016). " Statistics in Psychology and Education (2nd ed.).” Delhi, PHI Learning Pvt. Ltd.

[12] Singh, A., Kumari, S. and Singh, J. (2014). “ A Comparative Study of Environmental Awareness among Secondary School Teachers in Bareilly District U.P. India." Universal Journal of Environmental Research and Technology. 4(2), 60-64. 
[13] Sundar, I. (2006). “ Teaching and Learning Methods in Environmental Education” . New Delhi: Sarup Book Publishers Pvt. Ltd., 55.

[14] Sundaravalli, T. (2012). "Student-Teachers Awareness of Environmental Pollution." International Journal of Teacher Educational Research. 1(4), 52-58.

*Corresponding author.

E-mail address: dev007geo@gmail.com 